\title{
FDl in Pension in India: Opportunities and Challenges
}

\section{*Dr. Sakshi Vasudeva}

Effulgence

Vol. 11 No. 2

July - December, 2013

Rukmini Devi Institute of Advanced Studies

E-mail : effulgence@rdias.ac.in, Website : www.rdias.ac.in http://effulgence.rdias.ac.in/user/default.aspX

Abstract

https://dx.doi.org/10.33601/effulgence.rdias/v11/i2/2013/42-49

\begin{abstract}
Social Security for old age is one of the important challenges being faced by Indian Economy. The present study was conducted to examine the satisfaction level of organised sector of employees with the current provision for old age security in India and to know their opinion towards introduction of FDI in Pension in India. Response was collected from 100 respondents. Significant difference of opinion was found for the satisfaction level on account of gender. Females were found be bighly satisfied. Respondents agreed that introduction of FDI in pension would provide coverage for unorganized sector also; pension in private bands would not belp to cover people who pay small premiums; FDI in pension requires simultaneous existence of state financed schemes. Respondents were against the notion that the Pension Market should be fully opened up for foreign players. FDI in pension in India seems one of the most pressing requirements considering the growing life expectancy and inability of the government to provide universal state financed pension schemes in India. However, it is important to frame rational guidelines for such introduction.
\end{abstract}

Key-Words: Social Security, Life Expectancy, FDI (Foreign Direct Investment), Pension, Organised Sector of Employees, Universal State Financed Pension Schemes.

\section{INTRODUCTION}

Cocial Security for old age is one of the important $\checkmark$ challenges being faced by Indian Economy. The demographic statistics reveal average life expectancy of 77 years which is likely to rise to 80 years in the next three decades. The population above 60 years of age by 2030 will approach 200 million. According to census figures, the proportion of older people in India was 5.3 per cent in 1961, and is expected to reach 9.9 per cent in 2021'. Therefore, there is dire need that they should be protected against all the contingencies. That is possible, if they have adequate financial security during old age. But unfortunately, vast majority of India's population is not covered by any formal old-age income scheme and is dependent on their earnings or transfer from family members. This has been accompanied by broken traditional extended family make-up of households and families are now of nuclear set ups. People are migrating from their native places. ${ }^{1}$ During Old age, their earning capacity also reduces and they become more vulnerable and dependent on their family. ${ }^{2}$ The unorganised sectors of employees have no formal provision for pension. Even the working population in India is inadequately covered by some form of retirement benefit. Reforms are thus required to make a social security provision for growing number of senior citizens. There are generous pension schemes for public sector employees. Some of the private sector employees also have pension schemes, but $90 \%$ of Indian workers have no provision for formal pension arrangement.

1. There is also a growing trend of migration from rural to urban areas, leaving many older people without family support in rural areas (Help Age India, 2009).

2. For most of the people, old-age security is a combination of personal savings and support from the extended family (Goswami, 2002). 


\section{NEED OF INTRODUCING FDI IN PENSION IN INDIA}

In India, there is huge unorganized sector which is not covered by any kind of formal pension benefits. People are living longer than earlier. Indian Government can't bear the increased burden out of its state exchequer. Burden can't be put on employer only as it would interfere into free operation of the labour market. Low pension coverage and large workforce in the unorganized sector also provide massive opportunities for private sector and foreign players to enter pension market in India. Among others, there are numerous other reasons in support of growth of pension market:

Increasing Number of Dependents in the family: The population in India is on continuous rise in India which means higher number of dependents in the family.

Higher Savings Rate: Indian people are keen to save for the rainy day; even a small fraction of savings can do wonders if properly invested. Therefore, huge potential lies for private $\&$ foreign players to tap the savings.

Increasing Size of Elderly population: Both the share and size of elderly population is increasing over time. From $5.6 \%$ in 1961 it is projected to rise to $12.4 \%$ of population by the year 2026. The size of the elderly population has risen from 12.1 million in 1901 to approximately 77 million in Census 2001. According to official population projections, the number of elderly persons will rise to approximately 140 million by $2021 .^{3}$

Increase in life expectancy: The life expectancy at birth during 2002-06 was 64.2 for females as against 62.6 years for males. At age 60, average remaining length of life was found to be about 18 years (16.7 for males, 18.9 for females) and that at age 70 was less than 12 years (10.9 for males and 12.4 for females). This poses a serious pressure on the Government as it requires higher pension outlays and depleted savings. ${ }^{3}$

\section{Desire to maintain the same standard of living post retirement}

Pension Reforms: The Government of India has introduced various reforms in pension sector. Schemes like Provident Fund; State Financed Pension Schemes for older people are testimony to the fact that Indian Government is keen to protect people during old age.

Government is not financially capable to provide Universal State Financed Pensions: The pension liability of the Government runs in thousands of crores. According to an estimates by the researcher " The salary and pension payments account for a large proportion of both the central and state government expenditure, i.e. 9 per cent of GDP in 2003-04 compared with 7.9 per cent in 1990-91. There was an increase, i.e. 6,870 crore rupees in 1990-91 to 62,011 crore rupees in 2005-06. ${ }^{.4}$ The budgetary expenditure of the government on pension in 2010-11 and 2011-12 was Rs. 57,405 and 56,190 crore respectively. The estimated planned expenditure in 201213 is to the extent of Rs. 63,183 crores. ${ }^{5}$ Thus, the pension liability is growing and expected to mount higher pressure on the government exchequer. It does not seem sustainable in the future.

Inadequate Coverage of Formal Pension Schemes: According to an estimate, only $12.7 \%$ of population is covered under formal pension system. The rest of the population has no coverage for formal pension schemes. ${ }^{6}$

Huge Potential for Private Players to enter the Pension Market: Assocham ${ }^{7}$ said in its study Financial Markets: Time for Next Generation Reforms 'Over 80 per cent of the working people are in the unorganized sector without regular salary and benefits. The PF market is growing at a compounded annual growth rate (CAGR) of about 10 per cent, but there is enormous potential as more than 30 crore working people do not have formal pension benefits'.

3. Data gathered from report titled as 'Situation Analysis of Elderly in India', Central Statistics Office, Government of India.

4. An estimate of Irudaya Rajan, from budget statistics revealed the pension liability of Centre to the tune of Rs. 27,908 and of the state Rs. 34,103 making it total Rs.62, 011 in 2005-06.

5. Statistics on Revenue Expenditure from Indian Budget Estimates

6. Statistics on pension coverage in Handbook of Statistical Abstract, 2006

7. Assocham "As more and more working people join the organized sector, India's pension fund (PF) market is set to grow at a rapid pace to reach about Rs 20 lakb crore by 2015 from the present level of about Rs 15.4 lakb crore," 


\section{REVIEW OF LITERATURE}

Queisser, Monika; Whitehouse, Edward and Whiteford, Peter (2007) found that the future adequacy of public pension system is doubtful. Therefore, it is recommended in their study that a number of countries would need to further increase private provision in order to guarantee adequate future retirement incomes.

Oskari Juurikkala (2008) has argued in his paper that existing pension arrangements suffer from too much government involvement and too much regulation. The government should abolish unnecessary regulations in financial markets, make tax rules fairer and allow markets to provide the services that people need, as their needs evolve and as the economy develops.

Nicholas Barr and Peter Diamond (2009) concluded in their study that there is no single best pension design. He suggested that any improvement to the finances of a pension system must involve one or more of: higher contribution rates; lower benefits; later retirement with the same benefit; policies, such as increased saving designed to increase national output.

Pal, Sarmistha \& Palacios, Robert (2011) interpreted in their study that the evidence of an income-mortality link has, therefore, significant implications for pension policy. At the broadest level, low relative poverty rates actually would signal the extreme vulnerability of poor older people and provide support for this form of categorical targeting. The evidence holds out that in terms of design and eligibility parameters, the povertymortality link suggests that if targeting can be done in a cost-effective manner, it would be worth excluding the non-poor in order to reduce the eligibility age.

Reece, Christopher and G. SAM, Abdoul (2011) estimated that full privatization increased FDI as a percentage of GDP by about $57 \%$, ceteris paribus. Results would be relevant to broader discussions. Policymakers who confront the problem of pension reform may consider the potentially positive relationship between privatization and FDI inflows as an additional incentive to consider the measure.

Nicholl Kim (2012) concluded that when it comes to retirement plan design, one size will not fit all. The government/employers need to assess the extent to which benefits provide an "adequate" retirement income, examine how the plan distributes retirement risks between employers and employees and evaluate whether the plan is still meeting workforce management goals. Moreover, careful planning and quality analysis are the keys to a successful plan redesign effort.

Shi S-J, Mok K-H (2012) examined rationales and processes for pension privatisation in Taiwan, Hong Kong and mainland China since the 1990s. The diversification of pension privatisation manifests manifold institutional changes of old age security, and raise an essential governance issue for the regulation of funded pension provision to ensure adequate income for older people.

\section{SIGNIFICANCE OF THE STUDY}

Old age security is one of the pressing requirements of current time. The State alone can't bear the increasing burden of pension. The Government thought of introducing FDI in pension which raised lot of controversies. Hence, it initiated the researcher to study the employees' opinion towards current system of pension and various aspects of introduction of FDI in pension in India.

\section{OBJECTIVES OF THE STUDY}

The present study is conducted to know the opinion of organised sector of employees towards FDI in Pension in India with the following objectives :

1. To examine the satisfaction level with the current provision for old age security in India.

2. To examine the various aspects of introducing FDI in Pension.

3. To make various useful suggestions for better implementation of the policy.

\section{HYPOTHESIS OF THE STUDY}

Null Hypothesis $\left(\mathrm{H}_{01}\right.$ There is no significant difference of satisfaction level with the current system of pension on account of gender.

Null Hypothesis $\left(\mathrm{H}_{02}\right)$ There is no significant formation of opinion about various aspects of introduction of FDI in pension: 
$\mathrm{H}_{02 \mathrm{a}}$ : Introduction of FDI in pension would provide coverage for unorganized sector also.

$\mathrm{H}_{026}$ : Investors would be in a position to fetch better returns for invested money

$\mathrm{H}_{02 \mathrm{c}}$ Introduction of FDI in pension would generate funds for the development of the economy

$\mathrm{H}_{\text {02d. }}$ FDI in pension might be detrimental for employees as their all savings might be wiped out in private hands.

$\mathrm{H}_{\text {02e: }}$ Pension in private hands would not help to cover people who pay small premiums.

$\mathrm{H}_{\text {02f }}$ FDI in pension requires simultaneous existence of state financed schemes

$\mathrm{H}_{\text {02g: }}$ Pension Market should be fully opened up for foreign players

$\mathrm{H}_{02 \mathrm{~h}} \mathrm{FDI}$ in pension is an attempt to reduce the burden on the government to provide old age security to its citizens.

\section{RESEARCH METHODOLOGY}

The study is based on primary data. It is descriptive study and seeks to examine the opinion of organized sector of employees towards various aspects of pension in India. A survey was conducted among 100 respondents. The data was collected from the respondents residing in Delhi and NCR. Both government and private sector employees were included in the study. 85 per cent of respondents included in the study were Government Sector employees. A questionnaire was administered to the respondents. The questionnaire was designed after thorough review of available literature on the subject. Three point scale and rankings were used in the questionnaire. The study was an opinion based survey; therefore, for the analysis of data, simple percentages and Mean Values were used for the analysis. For testing of hypothesis, Chi Square Analysis and One Sample T Test were employed. The distribution was found to be normal for aspects of introduction of FDI in Pension; therefore parametric test was used for the analysis.

\section{ANALYSIS AND INTERPRETATION}

\section{Description of the Sample}

Out of the 100 respondents, 10 per cent of the respondents were having experience of less than 5 years,
$10 \%$ of the respondents were having experience of $5-10$ years and $80 \%$ of the respondents were having experience of more than 10 years. 44 per cent of the respondents were females and 56 per cent of the respondents were males. 20 per cent of the respondents were below 45 years and the rest i.e. $80 \%$ of them were above the age of 45 years. Out of the surveyed respondents, 100 per cent of them were covered under the pension scheme of the employer. 10 percent were covered under Voluntary Scheme, whereas 90 percent were covered under Mandatory Scheme.

\section{Opinion about Current Pension}

The respondents were asked about their current system of pension. $66 \%$ of the respondents were found to be satisfied with their current system, where as $34 \%$ of them were dissatisfied with the system. Cross tabulation was computed between gender and satisfaction with their current system of pension. The results showed that $100 \%$ of the females were satisfied, where as all the respondents who expressed dissatisfaction were males. Chi square results also showed significant association between gender and satisfaction. (See table I(a)and 1(b)) Null Hypothesis $\left(\mathrm{H}_{011}\right.$ stands rejected. There is significant difference of satisfaction level with the current system of pension on account of gender.

\section{(INSERT TABLES 1A AND 1B HERE)}

\section{Reasons for Dissatisfaction}

Those respondents who were dissatisfied with the current system, ranked some of the major reasons for their dissatisfaction. The lowest rank (i.e.; 1) was assigned to the most important reason and the highest rank (i.e.; 6) was assigned to the least important reason. Poor customer service was identified to be the most important reason followed by incomplete coverage. The respondents identified delay in settlement to be the least important reason.

\section{(INSERT TABLES 2 HERE)}

\section{Opinion about Introducing FDI in Pension in India}

42 percent of the respondents were in the favour of introducing FDI in pension in India, and the rest, that is 
58 percent of the respondents were against the introduction. Cross Tabulation was computed to understand the difference of opinion on account of gender.

\section{(INSERT TABLES 3 HERE)}

\section{Choice between Government Pension Schemes or Private Pension Schemes}

The response was highly skewed towards government pension schemes. 78 percent of the respondents preferred government pension schemes and only 22 percent of the respondents shared the contrary opinion in the favor of Private Pension Schemes.

\section{Various Aspects of Introduction of FDI in Pension in India}

Various important aspects of Introduction of FDI in Pension in India were administered to the respondents. The information was sought on three points Likert Scale (The values 1, 2 and 3 was used for agreement, neutral \& disagreement opinion respectively) Mean Values were computed. Cut off Point was fixed at 2 mean value, the values above 2 signifies disagreement and below 2 means agreement. The results are summarized in Table IV.

\section{(INSERT TABLES 4 HERE)}

Null Hypothesis $\left(H_{02)}\right.$ stands clearly accepted for the following aspects

$\mathrm{H}_{022}$ : Introduction of FDI in pension would generate funds for the development of the economy

$\mathrm{H}_{\text {02h: }}$ FDI in pension is an attempt to reduce the burden on the government to provide old age security to its citizens.

$\mathrm{H}_{\text {02d }}$ FDI in pension might be detrimental for employees as their all savings might be wiped out in private hands.

Significant Opinion could not be formed for the above aspects. However, the analysis of the averages revealed that there was neutral opinion about generating funds for the development of the economy and reducing the burden on the government. The examination of averages also showed that the respondents agreed that money is not safe in the hands of the private players.
Taking slightly bigher than 5\% significance level would make the score significant for the following as well

$\mathrm{H}_{\text {02b: }}$ Investors would be in a position to fetch better returns for invested money.

Null Hypothesis $\left(H_{02)}\right.$ stands rejected for some of the aspects. There is significant formation of opinion about the following aspects

$\mathrm{H}_{02 a}$ : Introduction of FDI in pension would provide coverage for unorganized sector also.

$\mathrm{H}_{022}$ Pension in private hands would not help to cover people who pay small premiums.

$\mathrm{H}_{\text {02f }}$ FDI in pension requires simultaneous existence of state financed schemes.

$\mathrm{H}_{\text {025: }}$ Pension Market should be fully opened up for foreign players.

\section{Findings of the study}

Complete Response was collected from 100 respondents. 44 per cent of the respondents were females and 56 per cent of the respondents were males. 20 per cent of the respondents were below 45 years and the rest i.e. $80 \%$ of them were above the age of 45 years. Out of the surveyed respondents, 100 per cent of them were covered under the pension scheme of the employer. 10 percent were covered under Voluntary Scheme, whereas 90 percent were covered under Mandatory Scheme.

The respondents were asked about their current system of pension. $66 \%$ of the respondents were found to be satisfied with their current system, where as $34 \%$ of them were dissatisfied with the system. Significant difference of opinion was found for the satisfaction level on account of gender. Females were found be highly satisfied.

Those respondents who were dissatisfied with the current system, ranked some of the major reasons for their dissatisfaction. Poor customer service was identified to be the most important reason followed by incomplete coverage. The respondents identified delay in settlement to be the least important reason.

42 percent of the respondents were in the favour of introducing FDI in pension in India, and the rest, that is 
58 percent of the respondents were against the introduction.

The response was highly skewed towards government pension schemes. 78 percent of the respondents preferred government pension schemes and only 22 percent of the respondents shared the contrary opinion in the favor of Private Pension Schemes.

Respondents agreed that Introduction of FDI in pension would provide coverage for unorganized sector also; pension in private hands would not help to cover people who pay small premiums; FDI in pension requires simultaneous existence of state financed schemes. Respondents were against the notion that the Pension Market should be fully opened up for foreign players. Respondents indicated that invested money would generate better returns.

\section{IMPLICATIONS OF THE PRESENT STUDY}

It is high time we realize that India would have to accept liberalization in the pension market also as the growing requirement of social security can't be simply put on family and Government alone. Based on the analysis of the data, the following are implications which are proposed for introducing FDI in pension in India:

- Protection of Invested Money of the People: The Indian Government should lay down strict financial parameters for insurance companies to enter the pension market so that these do not tend to be flyby- night companies and invested money of the people for their retirement age remains safe and secure. For both entry and exit, strict regulations and lot of safeguards need to be imposed to dispel the fear of losing invested money.

- Not More than $49 \%$ should be opened for foreign players. India is a mixed economy; we have vast proportion of people who can't access the formal pension market. Ours being a socialist economy also, the responsibility of the Government towards lower income strata remains coexistent with our goals. If the majority of the stake lies with India, it would be possible to press schemes meant for welfare of public in India, especially micro finance and micro insurance schemes.
Mandatory Guidelines to provide old age security against small premium amounts: One cannot ignore the fact that private companies operate for profit motive. All Indians are not self sustained to pay hefty premium amounts of private insurance companies. Therefore, it is required that insurance companies should be encouraged to create micro pension schemes where in small premiums are involved. Some reasonable amount of cess can also be imposed on private players in the pension market which can be targeted to provide low premium pension products to the masses. If this is not done, it would create inequality in the market as we could see from the experience of China.

\section{Simultaneous Existence of State Financed Schemes The most important fear of introducing FDI in pension that the Government should not adopt a lax attitude towards its responsibility for those people who can't pay premiums. Subject to means test, state financed pensions should continue and aim to have wider coverage of the population.}

- Universal Health Insurance with low premium amounts should also be introduced so that older people are able to maintain their health.

\section{CONCLUSIONS}

FDI in pension in India seems one of the most pressing requirements considering the growing life expectancy and inability of the government to provide universal state financed pension schemes in India. It would also generate funds for some of the goals of Indian Economy such as infrastructure. The other significant benefits include increase in the pension coverage and competition in the pension market. However, that does not mean that Government would be absolved from its responsibilities towards older people. The Government needs to ensure that the benefits of FDI in pension reaches even the poorest sections of the society by providing means tested old age pensions and micro financed pension schemes. It is vital to ensure that the invested money of the people remains safe. For which, the Government must frame rigorous guidelines for bringing FDI in pension in India. 


\section{REFERENCES}

1. ASSOCHAM (2012) “India's Experience with FDI, the Role of a Game Changer". Available at www.assocham.org

2. Barr Nicholas and Diamond Peter(2009), "Reforming pensions: Principles, analytical errors and policy directions", International Social Security Review, 62(2), 5-29

3. Goswami, R. (2002), "Old Age Protection in India: Problems and Prognosis", International Social Security Review, 55(2), 95-121.

4. Government of India (2011), "Situation Analysis of Elderly in India”, Central Statistics Office, Ministry of Statistics and Programme Implementation.

5. Government of India (2010-2011; 2011-12; 20122013), “Annual Report,” Budget Estimates, Ministry of Finance.

6. Government of India (2006), "Handbook of Statistical Abstract”, Ministry of Statistics and Programme Implementation.

7. HelpAge India (2009): The social pensions in India a participatory study on poverty reduction impact and role of monitoring groups. Policy briefing on social pension.

8. Irudaya Rajan, S(2010) "Demographic ageing and employment in India”, ILO publication.
9. Juurikkala Oskari (2008), "Sustainable Pension Reforms in India: Towards Market Based System, Institute of Economic Affairs", Blackwell Publishing, Oxford, 35-40.

10. Nicholl Kim (2012), "Re-examining Public Pension Plans: A Road Map for Decision Makers", Compensation \& Benefits Review 44(4) 230-233, SAGE Publications, http://cbr.sagepub.com/content/44/4/230

11. Queisser Monika, Whitehouse Edward and Whiteford Peter (2009), "The public-private pension mix in OECD countries", Industrial Relations Journal 38(6), 542-568.

12. Reece Christopher and G. Sam Abdoul (2011), "Impact of Pension Privatization on Foreign Direct Investment”, World Development 40(2), 291-302.

13. Sarmistha Pal \& Robert Palacios (2011), "Understanding Poverty among the Elderly in India: Implications for Social Pension Policy”, Journal of Development Studies, 47(7), 1017-1037.

14. Shi S-J, Mok K-H. (2012), "Pension privatisation in Greater China: institutional patterns and policy outcomes", International Journal of Social Welfare , Blackwell Publishing Ltd.

Table I(a): Cross Tabulation between Gender and Satisfaction with the Current System

\begin{tabular}{|llll|}
\hline Satisfaction with The Current system of Pension & Gender & Total \\
& Females & Males & \\
\hline Satisfied & 44 & 22 & 66 \\
Dissatisfied & 0 & 34 & 34 \\
Total & 44 & 56 & 100 \\
\hline
\end{tabular}

Table I(b): Chi Square Tests

\begin{tabular}{|l|l|l|l|l|l|}
\hline & Value & Df & Asymp. Sig. (2-sided) & Exact Sig. (2-sided) & Exact Sig. (1-sided) \\
\hline $\begin{array}{l}\text { Pearson Chi-Square } \\
\begin{array}{l}\text { Continuity Correction } \\
\text { Fisher's Exact Test }\end{array}\end{array}$ & $40.476^{\mathrm{a}}$ & 1 & .000 & & \\
N of Valid Cases & 37.816 & 1 & .000 & .000 & .000 \\
\hline
\end{tabular}

A. 0 cells $(.0 \%)$ have expected count less than 5 . The minimum expected count is 14.96 .

b. Computed only for a $2 \times 2$ table 
Table 2: Reasons for Dissatisfaction

\begin{tabular}{|l|l|l|}
\hline Problems & Mean Values & Ranking \\
\hline No Market Based Investment Returns & 3.71 & IV \\
Too much Paper Work & 4.71 & V \\
Delay in Settlement & 4.97 & VI \\
Incomplete Coverage & 2.68 & II \\
Overly Regulated & 3.25 & III \\
Poor Customer Service & 1.68 & I \\
\hline
\end{tabular}

Table 3: Should FDI be introduced In Pension in India?

\begin{tabular}{|llll|}
\hline Pension In India & $\begin{array}{l}\text { Gender } \\
\text { Females }\end{array}$ & Males & Total \\
\hline Yes & 10 & 32 & 42 \\
No & 34 & 24 & 58 \\
Total & 44 & 56 & 100 \\
\hline
\end{tabular}

Table 4: FDI in Pension in India

\begin{tabular}{|c|c|c|c|c|c|}
\hline S. No. & Particulars & Mean & Results & T values & $\begin{array}{l}\text { Significance } \\
\text { Level(two tailed) }\end{array}$ \\
\hline 1. & $\begin{array}{l}\text { Introduction of FDI in } \\
\text { pension would provide } \\
\text { coverage for unorganized } \\
\text { sector also. }\end{array}$ & 1.44 & Agreement & -6.725 & $\begin{array}{l}0.000 \\
\text { Highly } \\
\text { Significant }\end{array}$ \\
\hline 2. & $\begin{array}{l}\text { Investors would be in a } \\
\text { position to fetch better } \\
\text { returns for invested money }\end{array}$ & 1.78 & Agreement & -2.799 & $\begin{array}{l}0.006 \\
\text { Insignificant }\end{array}$ \\
\hline 3. & $\begin{array}{l}\text { Introduction of FDI in } \\
\text { pension would generate funds } \\
\text { for the development of the } \\
\text { economy }\end{array}$ & 2.01 & $\begin{array}{l}\text { In Favour of } \\
\text { Neutral } \\
\text { Opinion. }\end{array}$ & 0.122 & $\begin{array}{l}0.903 \\
\text { Insignificant }\end{array}$ \\
\hline 4. & $\begin{array}{l}\text { FDI in pension might be } \\
\text { detrimental for employees as } \\
\text { their all savings might be } \\
\text { wiped out in private hands. }\end{array}$ & 1.79 & Agreement & -2.272 & $\begin{array}{l}0.025 \\
\text { Insignificant }\end{array}$ \\
\hline 5. & $\begin{array}{l}\text { Pension in private hands } \\
\text { would not help to cover } \\
\text { people who pay small } \\
\text { premiums. }\end{array}$ & 1.77 & Agreement & -2.913 & $\begin{array}{l}0.004 \\
\text { Significant }\end{array}$ \\
\hline 6. & $\begin{array}{l}\text { FDI in pension requires } \\
\text { simultaneous existence of } \\
\text { state financed schemes }\end{array}$ & 1.11 & Agreement & -28.302 & $\begin{array}{l}0.000 \\
\text { Highly } \\
\text { Significant }\end{array}$ \\
\hline 7. & $\begin{array}{l}\text { Pension Market should be } \\
\text { fully opened up for foreign } \\
\text { players }\end{array}$ & 2.45 & $\begin{array}{l}\text { Disagreemen } \\
\text { t. }\end{array}$ & 5.400 & $\begin{array}{l}0.000 \\
\text { Highly } \\
\text { Significant }\end{array}$ \\
\hline 8. & $\begin{array}{l}\text { FDI in pension is an attempt } \\
\text { to reduce the burden on the } \\
\text { government to provide old } \\
\text { age security to its citizens. }\end{array}$ & 1.99 & $\begin{array}{l}\text { In Favour of } \\
\text { Neutral } \\
\text { Opinion. }\end{array}$ & -.122 & $\begin{array}{l}0.903 \\
\text { Insignificant }\end{array}$ \\
\hline
\end{tabular}

